\section{Arbuscular mycorrhizal fungi as a tool to ameliorate the phytoremediation potential of poplar: biochemical and molecular aspects}

\author{
Angela Cicatelli ${ }^{(1)}$, Patrizia Torrigiani ${ }^{(2)}$, Valeria Todeschini ${ }^{(3)}$, Stefania \\ Biondi $^{(4)}$, Stefano Castiglione ${ }^{(1)}$, Guido Lingua ${ }^{(3)}$
}

Poplar is a suitable species for phytoremediation, able to tolerate high concentrations of heavy metals (HMs). Arbuscular mycorrhizal fungi (AMF) form symbiotic associations with the roots of most land plants; they improve nutrient uptake and enhance phytoextraction of HMs while alleviating stress in the host plant. This review summarizes previous results from field and greenhouse studies conducted by us and dealing with this topic. In a field trial on a highly $\mathrm{Zn}$ - and $\mathrm{Cu}$-contaminated site, differences in plant survival and growth were observed among 168 clones originating from natural populations of Populus alba L. and Populus nigra L. from northern Italy. After two and a half years from planting, the density, activity and metabolic versatility of the culturable fraction of the soil bacteria in the HM-polluted field was higher in the soil close to where larger poplar plants were growing, in spite of comparable HM concentrations recorded in these soils. One well-performing clone of $P$. alba (AL35), which accumulated a higher concentration of both metals and had high foliar polyamine (PA) levels, was used for further investigation. In a greenhouse study, AL35 cuttings pre-inoculated with AMF (Glomus mosseae or Glomus intraradices) and then transferred to pots containing soil, collected from the HM-polluted site, displayed growth comparable to that of controls grown on unpolluted soil, in spite of higher $\mathrm{Cu}$ and $\mathrm{Zn}$ accumulation. Such plants also showed an overall up-regulation of metallothionein (MT) and PA biosynthetic genes, together with increased PA levels. A genome-wide transcriptomic (CDNA-AFLP) analysis allowed the identification of a number of genes, mostly belonging to stress-related functional categories of defense and secondary metabolism, that were differentially regulated in mycorrhizal vs. non mycorrhizal plants. A proteomic analysis revealed that, depending on sampling time, changes in protein profiles were differentially affected by AMF and/or HMs. It is concluded that soil-borne microorganisms affect plant performance on HMpolluted soil. In particular, mycorrhizal plants exhibited increased capacity for phytostabilization of HMs, together with improved growth. Their greater stress tolerance may derive from the protective role of PAs, and from the strong modulation in the expression profiles of stress-related genes and proteins.

Keywords: Arbuscular Mycorrhizae, Copper, Phytoremediation, Poplar, Proteome, Soil Bacteria, Transcriptome, Zinc

\footnotetext{
Introduction

Many large areas around the world are contaminated with heavy metals (HMs) and/or organic compounds; most of these have not been remediated due to the high cost and technical drawbacks of currently available technologies. HMs tend to accumulate in soils and aquatic sediments and can enter the food chain leading to the biomagnification phenomenon thereby representing a risk to the environment and to human health (Clijsters et al. 1999). Some essential elements, such as copper $(\mathrm{Cu})$ and zinc $(\mathrm{Zn})$, may be present in soils and waters at potentially toxic levels mainly as a result of agricultural
}

(1) Dipartimento di Chimica e Biologia, Università di Salerno, Fisciano (SA - Italy); (2) Dipartimento di Scienze Agrarie, Università di Bologna, Bologna (Italy); (3) Dipartimento di Scienze e Innovazione Tecnologica, Università del Piemonte Orientale, Alessandria (Italy); (4) Dipartimento di Scienze Biologiche, Geologiche e Ambientali, Università di Bologna, Bologna (Italy)

\section{@, Stefania Biondi \\ (stefania.biondi@unibo.it)}

Received: May 28, 2013 - Accepted: Dec 31, 2013

Citation: Cicatelli A, Torrigiani P, Todeschini V, Biondi S, Castiglione S, Lingua G, 2014. Arbuscular mycorrhizal fungi as a tool to ameliorate the phytoremediation potential of poplar: biochemical and molecular aspects. iForest 7: 333-341 [online 2014-04-17] URL: http://www. sisef.it/iforest/contents/?id=ifor1045-007

Communicated by: Alberto Santini

2011, Punshon \& Dickinson 1997, Sebastiani et al. 2004). In Italy, $P$. alba (white poplar) and P. nigra (black poplar) populations of the Ticino river valley constitute a hotspot of biodiversity (Castiglione et al. 2009, 2010, Fossati et al. 2004). Their genetic variability is being exploited for the selection of genotypes having interesting traits, such as tolerance to pollutants. The remarkable clonal variability of poplar allows to identify genotypes with a greater ability to accumulate/tolerate pollutants including heavy metals (Dos Santos Utmazian et al. 2007, Kopponen et al. 2001, Laureysens et al. 2004, Punshon \& Dickinson 1997, Zalesny et al. 2005). Finally, poplar offers the advantage that, being the first "model tree species" whose genome has been sequenced (Tuskan et al. 2004), physiological and molecular mechanisms at the basis of metal tolerance can be more easily investigated at the transcriptomic level (Di Baccio et al. 2011).

Plant symbiotic fungi, such as mycorrhizae, and soil bacteria can confer increased tolerance to stress (Gamalero et al. 2009). Arbuscular mycorrhizal fungi (AMF) form associations with the roots of the vast majority of land plants; the fungus colonizes the roots and forms arbuscules within root cortical cells thus improving plant nutrient uptake, especially phosphorus (Smith \& Read 1997). Moreover, increasing evidence shows that symbiotic fungi contribute to plant adaptation to multiple biotic and abiotic stresses (Gohre \& Paszkowski 2006, Lebeau et al. 2008, Lingua et al. 2002, Liu et al. 2007, Rodriguez \& Redman 2008, Smith et al. 2010). In the case of HMs, the beneficial ef- 
fect varies according to plant and fungal species, metal and concentration (Bois et al 2005, Lebeau et al. 2008, Takacs et al. 2005, Todeschini et al. 2007). The mechanisms by which AMF offer protection from stress have not been clarified, although decreased metal uptake has been reported in some cases (Christophersen et al. 2012, Mrnka et al. 2012). The potential of plant-microbe interactions in enhancing phytoremediation potential has been reviewed extensively elsewhere (Doty 2008, Lebeau et al. 2008, Rajkumar et al. 2012). Also in poplar, the effects of bacterial endophytes (van der Lelie et al. 2009), and of endo- and ectomycorrhiza (Mrnka et al. 2012) on phytoremediation capacity have been described.

Information regarding basic molecular processes underlying metal detoxification/tolerance is scarce especially in tree species. Metallothioneins (MTs) are among the plan components that respond to metal stress. MTs are small proteins encoded by a multigene family whose members appear to be differentially regulated in relation to organ and developmental stage, and in response to a number of stimuli including HMs (Cobbet \& Goldsbrough 2002). A role for MTs in HM detoxification and homeostasis has been proposed either because they bind to HMs or because they function as antioxidants (Akashi et al. 2004). The evidence is largely based on MT gene expression studies and yeast complementation experiments with plant MT genes, and some of it comes from studies on poplar species or hybrids (Balestrazzi et al 2009, Castiglione et al. 2007, Hassinen et al. 2009, Kohler et al. 2004).

Polyamines (PAs) are organic polycations regarded as plant growth regulators (Bagni \& Torrigiani 1992); putrescine (Put), spermidine $(S p d)$ and spermine $(S p m)$, the most abundant PAs in plants, occur both in free and conjugated forms, the latter mainly represented by phenylamides (products of the covalent binding of PAs with hydroxycinnamic acids - Martin Tanguy 1997). Due to their transcriptional and translational effects free PAs are essential for normal growth and development of eukaryotic organisms (Kusano et al. 2008). In addition, there is abundant evidence for a stress protective role of PAs. Such evidence clearly arises from increased tolerance to multiple types of abiotic stress in plants that over-express PA biosynthetic genes (Abou-Shanab et al. 2008, Alcazar et al. 2010, Groppa \& Benavides 2008, Prabhavathi \& Rajam 2007), and from experiments in which plants were treated with exogenous PAs (Groppa et al. 2007, Prabhavathi \& Rajam 2007, Velikova et al. 2000). Although the exact mechanism is still unclear, PAs may act as free radical scavengers, stabilize membranes and retard senescence (Sharma \& Dietz 2006). Up-regulation of PA metabolism has been reported in poplars exposed to high $\mathrm{Zn}$ or $\mathrm{Cu}$ concentrations under in vitro (Franchin et al. 2007) or greenhouse/pot (Lingua et al. 2008) conditions and has been shown to correlate with the extent of metal tolerance.

The present review summarizes the results of our studies carried out in the last ten years, aimed at: (i) field screening for metal tolerance and accumulation of poplar clone collections established on a $\mathrm{Cu}-$ and $\mathrm{Zn}$-polluted site; (ii) analyzing the microbial populations present in the poplar plantation on the polluted site; (iii) investigating the effect of AMF on a tolerant poplar clone selected on the polluted site; (iv) monitoring the changes in some molecular/biochemical parameters involved in stress responses; and (v) analyzing the transcriptome and proteome changes elicited in leaves by $\mathrm{HM}$ and/or AMF.

\section{Field screening of tolerant poplar clones}

After assessing their genetic dissimilarity through Amplified Fragment Length Polymorphism (AFLP) analysis, more than 2000 cuttings of 168 different poplar clones (40 clones of $P$. alba and 128 clones of $P$. nigra) collected along the banks of the Ticino river (near Pavia, Italy) were planted in March 2003 on a highly $\mathrm{Cu}-$ and $\mathrm{Zn}$-polluted soil (ca. 900 and $1200 \mathrm{mg} \mathrm{kg}^{-1}$ dry weight soil, respectively in the top $60-\mathrm{cm}$ layer) close to an industrial plant. The clones were screened for survival and growth at the end of two consecutive growing seasons; metal accumulation in plant organs and leaf PA concentrations were determined in the best performing ones (Castiglione et al. 2009). After the first growth season, survival ranged from 0 to
$80 \%$ (Tab. 1); clones with more than $45 \%$ survival varied from 20 to $28 \%$, the latter in the $P$. alba collection named AL. This confirmed the large clonal variability of poplar, according to previous reports on Salicaceae (Aravanopoulos et al. 1999) and their mainly sexual reproduction (Smulders et al. 2008). Survival after the second growth season positively correlated $\left(\mathrm{R}^{2}=0.75-0.95\right)$ with plant size at the end of the first season, thus confirming the evidence that individuals with a larger biomass had a higher probability of survival (Zalesny et al. 2005).

Six of the best-performing poplar clones were selected for further analyses. After the first growth season the highest amount of $\mathrm{Zn}$ was found in the leaves, as compared with stem and roots, in agreement with previous results in Salix and Populus (Dos Santos Utmazian \& Wenzel 2007, Laureysens et al. 2004) indicating that $\mathrm{Zn}$ is efficiently translocated from the roots and accumulated in the leaves (Tab. 1). The clone named AL35 exhibited the highest concentration of $\mathrm{Zn}$ in all three organs as compared with the other clones. AL35 also displayed a high capacity for accumulating $\mathrm{Cu}$, whose concentration exceeded several fold that found in other clones, particularly in the roots; the latter is in accordance with the low translocability of this metal (Borghi et al. 2007, Kopponen et al. 2001, Todeschini et al. 2007).

The measure of foliar free and conjugated PA levels in the same plants confirmed that AL35 has outstanding features (Tab. 2). Although clonal variability was less accentuated than variability in metal accumulation capacity, AL35 stood out for its very high PA levels, with a prevalence of conjugated forms, which reached, in the case of Put, a concentration 18-fold higher than that of other clones. The prevalence of conjugated PAs relative to the free forms is consistent with the abundance of phenolic compounds in poplar tissues (Tsai et al. 2006). The strong positive correlation across clones between foliar levels of PAs and root $\mathrm{Cu}$ concentration $\left(\mathrm{R}^{2}=0.79\right.$ for total PAs) suggested that $\mathrm{Cu}$ rather than $\mathrm{Zn}$ drove the longterm PA response. In fact, $\mathrm{Cu}$ is considered more toxic than $\mathrm{Zn}$, and has been demonstrated to induce differential responses in terms of growth and PA accumulation also

Tab. 1 - Survival percentage and metal concentrations in selected poplar clones (AL22, AL35, NG12, NG19, SN26 and SN56) growing on a contaminated site at the end of the first growth season. Data are the mean $\pm \mathrm{SE}$.

\begin{tabular}{|c|c|c|c|c|c|c|c|}
\hline \multirow{3}{*}{ Poplar clone } & \multirow{3}{*}{$\begin{array}{c}\text { Survival } \\
\text { percentage } \\
(\%)\end{array}$} & \multicolumn{6}{|c|}{ Metals (mg kg-1 dry weight) } \\
\hline & & \multicolumn{3}{|c|}{$\mathrm{Cu}$} & \multicolumn{3}{|c|}{$\mathbf{Z n}$} \\
\hline & & Leaves & Stems & Roots & Leaves & Stems & Roots \\
\hline AL22 & 66.7 & $404 \pm 22$ & $37 \pm 8$ & $78 \pm 53$ & $845 \pm 77$ & $125 \pm 27$ & $97 \pm 30$ \\
\hline AL35 & 75 & $236 \pm 50$ & $109 \pm 13$ & $568 \pm 174$ & $2533 \pm 234$ & $710 \pm 23$ & $1159 \pm 219$ \\
\hline NG12 & 75 & $162 \pm 7$ & $34 \pm 1$ & $71 \pm 6$ & $2012 \pm 246$ & $672 \pm 26$ & $263 \pm 9$ \\
\hline NG19 & 50 & $190 \pm 10$ & $25 \pm 10$ & $50 \pm 10$ & $1076 \pm 156$ & $238 \pm 10$ & $137 \pm 10$ \\
\hline SN26 & 66.7 & $171 \pm 10$ & $57 \pm 18$ & $178 \pm 18$ & $1889 \pm 223$ & $552 \pm 22$ & $182 \pm 4$ \\
\hline SN56 & 75 & $132 \pm 13$ & $20 \pm 23$ & $81 \pm 23$ & $879 \pm 189$ & $151 \pm 6$ & $202 \pm 62$ \\
\hline
\end{tabular}


Tab. 2 - Free and conjugated polyamine levels in selected poplar clones (AL22, AL35, NG12, NG19, SN26 and SN56) growing on a contaminated site at the end of the second growth season. Data are the mean \pm SE. (Put): putrescine; $(S p d)$ : spermidine; $(S p m)$ : spermine.

\begin{tabular}{|c|c|c|c|c|c|c|}
\hline \multirow{3}{*}{$\begin{array}{c}\text { Poplar } \\
\text { clone }\end{array}$} & \multicolumn{6}{|c|}{ Polyamines (nmol g ${ }^{-1}$ fresh weight) } \\
\hline & \multicolumn{3}{|c|}{ Free } & \multicolumn{3}{|c|}{ Conjugated } \\
\hline & Put & Spd & Spm & Put & Spd & Spm \\
\hline$\overline{\text { AL22 }}$ & $20.4 \pm 4.6$ & $32.4 \pm 3.4$ & $20.2 \pm 0.6$ & $284.0 \pm 41.0$ & $102.0 \pm 20.0$ & $8.0 \pm 1.0$ \\
\hline AL35 & $360.8 \pm 17.8$ & $54.1 \pm 3.4$ & 0.0 & $1853.8 \pm 151.5$ & $287.7 \pm 11.8$ & 0.0 \\
\hline NG12 & $35.9 \pm 5.3$ & $22.7 \pm 2.4$ & $3.8 \pm 0.1$ & $205.4 \pm 54.1$ & $74.1 \pm 6.0$ & 0.0 \\
\hline NG19 & $33.3 \pm 2.2$ & $25.3 \pm 5.9$ & $6.5 \pm 1.8$ & $162.3 \pm 0.8$ & $221.4 \pm 13.0$ & 0.0 \\
\hline SN26 & $54.3 \pm 0.9$ & $67.0 \pm 2.6$ & $25.6 \pm 2.8$ & $115.0 \pm 45.8$ & $129.5 \pm 55.0$ & $31.0 \pm 3.0$ \\
\hline SN56 & $22.4 \pm 1.2$ & $57.1 \pm 2.9$ & $10.4 \pm 0.3$ & $109.0 \pm 15.0$ & $105.0 \pm 15.0$ & 0.0 \\
\hline
\end{tabular}

in micropropagated white poplar (cv. "Villafranca") shoots cultured in vitro (Franchin et al. 2007). Thus, in clone AL35 grown on the polluted site, the higher free and conjugated Put levels were associated to the very high concentration of both HMs accumulated in all three organs. Given that AL35 also exhibited a very high survival rate $(75 \%)$, its capacity to synthesize and accumulate large amounts of Put likely contributed to its tolerance to HMs. It has been suggested that PAs may protect the plant through reduction of oxidative damage/lipid peroxidation by free radical scavenging and even metal chelation (Groppa \& Benavides 2008, Lovaas 1997, Sharma \& Dietz 2006).

\section{Survey of soil microbial populations associated to poplar in the polluted site}

The importance of rhizosphere bacteria in growth and development of their host plants, and the use of microorganisms or their genes for engineering plants in enhancing phytoremediation is still underestimated (Doty 2008, Frey et al. 2010), even though there is clear evidence that metal phytoextraction and accumulation in plants can be affected by soil microorganisms (Abou-Shanab et al. 2008, Shilev et al. 2001, Solis-Dominguez et al. 2011).

A second experimental plot was established next to the previous one on the same $\mathrm{Cu}-$ and $\mathrm{Zn}$-polluted site (where the first poplar clone screening was performed) using the best performing white and black poplar clones from the previous trial and the commercial hybrid poplar clone I-214 (Populus $\times$ canadensis Moench) as a spacer between different clones (Gamalero et al. 2012). Although the overall survival of the clones confirmed previous results, cuttings from the same clone showed a marked variability in terms of survival and growth in different zones of the field ("position effect"). After checking that there were no significantly different $\mathrm{Cu}, \mathrm{Zn}$ and phosphorus concentrations in the soil in the different zones, we turned our attention to the soil microbial populations. After two and a half years from planting, microbiological and molecular analyses were focused on microbial populations col- lected in proximity of the roots of large and small I-214 trees, as well as in the soil with no plants (bulk soil - Gamalero et al. 2012). I-214 trees were chosen because they were more abundant than any other tested clone (being used as spacer, their number equaled the sum of all the individuals of the other clones under study); furthermore, they were very evenly distributed on the area chosen for the study. In agreement with the "rhizosphere effect" (Hartmann et al. 2008), results showed that the density, activity and metabolic versatility of the culturable fraction of the bacteria tended to increase from the bulk soil to the soil collected beneath the large I-214 trees. Overall, about 100 culturable bacterial strains were isolated and identified from the three different soil samples (bulk soil, small I-214, and large I-214). The Denaturing Gradient Gel Electrophoresis (DGGE) profiles of the culturable fraction revealed differences in bacterial populations depending upon the soil sample. In bulk soil, all the isolated strains were Gram positive, including sporulating (Bacillus sp.) and non sporulating ( $A r-$ throbacter and Streptomyces spp.) species. Two Gram negative species (Chryseobacterium soldanellicola and Variovorax parado$x u s)$ were preferentially associated with the poplar-planted soils. C. soldanellicola has never been reported to be tolerant to HMs, and it was previously isolated only from roots of sand-dune plants (Park et al. 2006). On the other hand, $V$. paradoxus has been found to promote plant growth under stress conditions probaly due to its ability to synthesize 1-aminocyclopropane-1-carboxylate (ACC) deaminase, an enzyme which modu-

Tab. 3 - Leaf, stem and root biomass (mean g dry weight plant ${ }^{-1}$ ) of $P$. alba clone AL35 after two seasons of growth (S3) in the greenhouse on unpolluted (NP) or polluted (P) soil in the absence or in the presence of either G. mosseae $(\mathrm{Gm})$ or $G$. intraradices $(\mathrm{Gi})$. Data are the mean $\pm \operatorname{SE}(n=3)$.

\begin{tabular}{lccc}
\hline \multirow{2}{*}{ Treatment } & \multicolumn{3}{c}{ Biomass } \\
\cline { 2 - 4 } & Leaves & Stems & Roots \\
\hline NP & $3.88 \pm 0.82$ & $10.31 \pm 4.71$ & $5.32 \pm 2.94$ \\
NP-Gm & $0.76 \pm 0.01$ & $12.69 \pm 3.14$ & $3.13 \pm 1.15$ \\
NP-Gi & $2.17 \pm 0.23$ & $7.20 \pm 0.91$ & $3.29 \pm 0.16$ \\
P & $0.51 \pm 0.07$ & $1.31 \pm 0.08$ & $0.79 \pm 0.07$ \\
P-Gm & $2.82 \pm 0.16$ & $8.24 \pm 2.93$ & $4.88 \pm 1.80$ \\
P-Gi & $0.44 \pm 0.04$ & $8.31 \pm 0.56$ & $3.40 \pm 0.84$ \\
\hline
\end{tabular}

lates the level of the stress hormone ethylene in plants (Belimov et al. 2001). In the soil surrounding the large I-214 poplar plants, Flavobacterium was the prevalent genus. Flavobacteria are found in the soil and rhizosphere where they tolerate high levels of major pollutants, including HMs (Kuffner et al. 2008, Piotrowska-Seget et al. 2005), and promote plant growth under natural and stressful conditions (He et al. 2010, Kuffner et al. 2008). Both culture-independent methods for the whole bacterial community and vealed a larger biodiversity in the poplar-associated soil samples as compared to the bulk soil, strongly suggesting that poplar trees select and increment the rhizosphereassociated microflora, possibly through the release of root exudates.

\section{Arbuscular mycorrhizal fungi improve biomass production on polluted soil}

Given the interesting features of AL35, the in poplar tolerance to $\mathrm{Cu}$ and $\mathrm{Zn}$ using this clone. To this aim, poplar cuttings were preinoculated as described in Lingua et al. (2008), or not inoculated (controls), with either Glomus mosseae $(\mathrm{Gm})$ or G. intraradices (Gi), now Funneliformis mosseae and Rhizophagus intraradices, respectively, according to the reviewed Glomeromycota classification by Schüßler \& Walker (2010). After one month cuttings were transferred to pots containing the same polluted $(\mathrm{P})$ soil collected from the experimental site, or non polluted (NP) agricultural soil, and grown DGGE analysis of the culturable fraction renext step was to investigate the role of AMF 
Tab. 4 - $\mathrm{Cu}$ and $\mathrm{Zn}$ concentrations in leaves, stems and roots of $P$. alba clone AL35 after two seasons of growth (S3) in the greenhouse on unpolluted (NP) or polluted $(\mathrm{P})$ soil in the absence or in the presence of either $G$. mosseae $(\mathrm{Gm})$ or $G$. intraradices (Gi). Data are the mean \pm SE.

\begin{tabular}{|c|c|c|c|c|c|c|}
\hline \multirow{3}{*}{ Treatment } & \multicolumn{6}{|c|}{ Metals (mg kg-1 dry weight) } \\
\hline & \multicolumn{3}{|c|}{$\mathbf{C u}$} & \multicolumn{3}{|c|}{ Zn } \\
\hline & Leaves & Stems & Roots & Leaves & Stems & Roots \\
\hline $\mathrm{NP}$ & $13.76 \pm 1.3$ & $8.45 \pm 0.6$ & $37.13 \pm 3.2$ & $385.22 \pm 34.6$ & $82.09 \pm 7.2$ & $92.24 \pm 8.2$ \\
\hline NP-Gm & $12.08 \pm 0.9$ & $5.71 \pm 0.5$ & $14.21 \pm 1.2$ & $269.22 \pm 24.2$ & $82.99 \pm 7.5$ & $43.79 \pm 3.8$ \\
\hline NP-Gi & $13.01 \pm 1.2$ & $5.73 \pm 0.5$ & $15.72 \pm 1.4$ & $284.97 \pm 26.0$ & $76.19 \pm 6.9$ & $37.87 \pm 3.3$ \\
\hline $\mathrm{P}$ & $20.16 \pm 1.7$ & $19.07 \pm 1.7$ & $97.56 \pm 8.6$ & $387.12 \pm 34.9$ & $126.96 \pm 11.2$ & $98.50 \pm 8.8$ \\
\hline $\mathrm{P}-\mathrm{Gm}$ & $31.86 \pm 2.7$ & $7.72 \pm 0.6$ & $605.47 \pm 54.3$ & $532.63 \pm 47.8$ & $63.76 \pm 5.7$ & $212.11 \pm 19.1$ \\
\hline P-Gi & $26.90 \pm 2.3$ & $5.66 \pm 0.5$ & $244.69 \pm 21.8$ & $461.18 \pm 41.7$ & $116.40 \pm 10.5$ & $115.76 \pm 10.3$ \\
\hline
\end{tabular}

for two vegetative seasons (2006-2007) in a greenhouse. Leaf sampling was performed four (S1, July 2006), six (S2, September 2006) and 16 months (S3, July 2007) after cutting transplanting. At the end of the experiment (S3), the extent of mycorrhization (5-23\%), though fairly low, was in line with previous reports (Quoreshi \& Khasa 2008). At this time, plant biomass was severely affected by HMs in the absence of AMF (up to $85 \%$ growth inhibition - Tab. 3). Interestingly, both fungal species restored plant biomass to control levels (Tab. 3), despite the generally higher HM accumulation in plant organs of mycorrhizal plants compared with those of non mycorrhizal ones (Tab. 4). In particular, $\mathrm{Cu}$ concentration was enhanced by both AMF in leaves and roots, while that of $\mathrm{Zn}$ was only enhanced by $\mathrm{Gm}$ in the roots. The total amount of metal accumulated by poplar organs, especially the roots, also increased dramatically in mycorrhizal plants (i.e., 10 and 37 fold in the case of $\mathrm{Cu}$, and 12.5 and 5 fold in the case of $\mathrm{Zn}$ for $\mathrm{Gm}$ and Gi, respectively - Cicatelli et al. 2010). In some non-woody plants, both monocot and dicot, increased uptake of metals $(\mathrm{As}, \mathrm{Cu}$, $\mathrm{Zn)}$ was reported in mycorrhizal plants as compared with non-mycorrhizal ones (Hua et al. 2010, Tseng et al. 2009)

Growth inhibition is a frequent symptom of HM phytotoxicity. Although the two fungal species can exert differential effects (Lingua et al. 2008) in AL35 plants grown on P soil the restoration of biomass production by preinoculation with AMF indicates that mycorrhization exerted a strong protective effect against HM toxicity. The higher phosphorus concentration in mycorrhizal roots suggests that growth recovery was due at least in part to the improved nutritional status, and certainly not to the reduced HM uptake. The mechanism by which the fungal symbionts exerted their protective role has been the focus of our further investigations.

\section{Metallothioneins are up-regulated in mycorrhizal plants}

Mycorrhizal plants grew better than their non-mycorrhizal counterparts though accumulating more $\mathrm{Cu}$ and $\mathrm{Zn}$, suggesting the presence of detoxifying mechanisms arising from cellular molecular and biochemical processes. Quantitative RT-PCR was performed to investigate the steady-state transcript levels of the poplar MT multi-gene family in mycorrhizal plants compared with non-mycorrhizal ones grown on either $\mathrm{P}$ or NP soil (Cicatelli et al. 2010). In P soil, both AMF strongly up-regulated the expression of both $a$ and $b$ isogenes of PaMT1, PaMT2 and PaMT3 both at the first (S1) and third (S3) leaf sampling (Tab. 5). The largest increase was observed for PaMTla in leaves of Gm

Tab. 5 - Modulation of poplar MT (MT1 to 3, isoforms $a$ and $b$ ), ADC and SPDS (1 and 2) gene transcript levels in leaves of $P$. alba clone AL35 after 4 months (S1) and 16 months (S3) of growth in the greenhouse on polluted (P) soil in the absence or in the presence of either $G$. mosseae $(\mathrm{Gm})$ or $G$. intraradices. Leaf mRNA levels were quantified by real-time RT-PCR and normalized with respect to actin. Arrows indicate alterations in gene expression relative to non mycorrhizal plants (on $\mathrm{P}$ soil).

\begin{tabular}{|c|c|c|c|c|}
\hline \multirow{2}{*}{ Genes } & \multicolumn{2}{|c|}{ S1 } & \multicolumn{2}{|c|}{ S3 } \\
\hline & P-Gm & P-Gi & P-Gm & P-Gi \\
\hline PAMT1a & $\uparrow$ & $\uparrow$ & $\uparrow$ & $\uparrow$ \\
\hline$P A M T 1 b$ & $\uparrow$ & $\uparrow$ & $\uparrow$ & $\uparrow$ \\
\hline PAMT2a & $\uparrow$ & $\uparrow$ & $\uparrow$ & $\uparrow$ \\
\hline$P A M T 2 b$ & $\uparrow$ & $\uparrow$ & $\uparrow$ & $\uparrow$ \\
\hline РАMT3a & $\downarrow$ & $\uparrow$ & $\uparrow$ & $\uparrow$ \\
\hline РАMT3b & $\uparrow$ & $\uparrow$ & $\uparrow$ & $\uparrow$ \\
\hline$P a A D C$ & $\uparrow$ & $\uparrow$ & $\leftrightarrow$ & $\leftrightarrow$ \\
\hline PaSPDS1 & $\downarrow$ & $\uparrow$ & $\uparrow$ & $\uparrow$ \\
\hline PaSPDS2 & $\downarrow$ & $\uparrow$ & $\downarrow$ & $\uparrow$ \\
\hline
\end{tabular}

plants. Overall, these results suggest that MTs may indeed afford protection against HM-induced stress, as previously reported in Pisum (Rivera-Becerril et al. 2005). MTs probably exert an antioxidant function as reported in transgenic $P$. alba cv. Villafranca plantlets over-expressing a pea MT2 gene (Balestrazzi et al. 2009). Although no correlation was found between MT expression and leaf metal concentration at S3 (but not $\mathrm{S} 1$ ), roots of mycorrhizal plants had accumulated one or both metals at higher concentration than controls. This would suggest that a signal coming from roots induced an up-regulation of all leaf MT mRNAs even before the plants had translocated and accumulated the metals at the leaf level. Moreover, since the fungus alone did not induce up-regulation of any of the MT isogenes on NP soil (Cicatelli et al. 2010), it appears that both high metal concentration and AMF are needed to trigger such induction. This has been confirmed by more recent results from a genome-wide transcriptomic analysis (Cicatelli et al. 2012). By contrast, in Brassica and in tomato, a decrease in MT expression was reported in mycorrhizal as compared with nonmycorrhizal plants. However, in tomato this was associated with lowered metal concentration in mycorrhizal plants (Dabrowska et al. 2012, Ouziad et al. 2005), in contrast to the results obtained from the clone AL35.

\section{Plant PA metabolism positively responds to mycorrhization}

In the field trial on the polluted site, the high-performing AL35 clone exhibited an endogenous concentration of Put that was 18fold higher than in the other clones. This corroborates the idea that PAs have a major role in conferring metal tolerance to plants. In subsequent greenhouse experiments performed with this clone, a different response to AMF inoculation was observed for genes encoding for the PA biosynthetic enzymes arginine decarboxylase (ADC), responsible for Put biosynthesis, and spermidine synthase (SPDS), which forms Spd from Put. Transcriptional changes associated with colonization by $G$. mosseae or $G$. intraradices in roots of Medicago truncatula Gaertn. also 
revealed several hundred genes that were either up- or down-regulated by only one of the two fungal species (Hohnjec et al. 2005). At first sampling (S1), an up-regulation of PaADC occurred in leaves of mycorrhizal AL35 plants grown on P soil relative to nonmycorrhizal controls, while at third sampling (S3) $P a A D C$ was down-regulated in the same plants (Tab. 5). PaADC up-regulation is in line with the purported role of this enzyme in plant responses to different stresses including metal stress (Alcazar et al. 2010, Groppa \& Benavides 2008, Prabhavathi \& Rajam 2007). No Put was accumulated possibly because it was transformed into $S p d$ and/or Spm. At third sampling, PaSPDS1 and $P a S P D S 2$ transcripts were both induced by AMF (Tab. 5). As a result of PaSPDS upregulation, free $S p d$ titres were higher in the presence than in the absence of AMF and correlated with improved plant growth; conjugated $S p d$ and Spm levels were also dramatically enhanced in plants inoculated with G. intraradices relative to uninoculated controls. Although enhanced Put titres seem to be the common physiological response to HM stress (Castiglione et al. 2009, Franchin et al. 2007, Groppa \& Benavides 2008, Lei et al. 2007), the accumulation of the higher PAs Spd and Spm seems to be typical of mycorrhizal plants grown under abiotic stress (Sannazzaro et al. 2007). The positive role of PAs, especially $S p d$ and Spm, possibly relies on their polycationic nature allowing a high biological activity (Hanfrey et al. 2002), such as binding with charged macromolecules. PAs may also afford protection from HM-induced stress by exerting an antioxidant activity, and/or by chelating metals (Groppa et al. 2007, Kuthanova et al. 2004). Moreover, the singlet oxygen quenching capacity of phenylamides and their free radical scavenging properties have been established (Edreva et al. 2007). These molecules are regarded as end-products of cellular metabolism (secondary metabolites), and long-distance signalling from mycorrhizal roots has been previously reported (Copetta et al. 2006, Guerrieri et al. 2004), resulting in the enhancement of secondary metabolite production in leaves.

\section{The leaf transcriptome and proteome are modulated in mycorrhizal plants}

\section{Transcriptome analysis}

Given the beneficial effects of AMF inoculation on poplar trees grown on HM-contaminated soil and the modified expression of major stress-related genes by fungal symbiosis, the hypothesis that a broader range of genes is involved in the improved growth performance of mycorrhizal AL35 plants on $\mathrm{P}$ soil relative to non-mycorrhizal ones was pursued. A genome-wide transcriptomic ana-

Tab. 6 - Modulation of transcript levels of genes selected, following a cDNA-AFLP analysis, in leaves of $P$. alba clone AL35 after 4 months (S1) of growth in the greenhouse on polluted (P) soil in the absence or in the presence of either G. mosseae $(\mathrm{Gm})$ or $G$. intraradices (Gi). Leaf mRNA levels were quantified by real-time RT-PCR and normalized with respect to actin. Arrows indicate alterations in gene expression relative to non mycorrhizal plants grown on NP soil.

\begin{tabular}{lccc}
\hline \multirow{2}{*}{ Genes } & & S1 & \\
\cline { 2 - 4 } & P & P-Gm & P-Gi \\
\hline Clathrin protein & $\uparrow$ & $\downarrow$ & $\downarrow$ \\
Phytochelatin synthase & $\uparrow$ & $\leftrightarrow$ & $\uparrow$ \\
Chlorophyll binding protein & $\leftrightarrow$ & $\uparrow$ & $\uparrow$ \\
Pyridoxine-5'-phosphate oxidase & $\leftrightarrow$ & $\uparrow$ & $\uparrow$ \\
Nuclear transport factor 2 & $\leftrightarrow$ & $\uparrow$ & $\uparrow$ \\
Teosinte-branched-like protein & $\leftrightarrow$ & $\uparrow$ & $\leftrightarrow$ \\
S-adenosylmethionine-dependent methyltransferase & $\leftrightarrow$ & $\uparrow$ & $\leftrightarrow$ \\
Glutathione synthase & $\leftrightarrow$ & $\uparrow$ & $\uparrow$ \\
Thaumatin like protein & $\leftrightarrow$ & $\leftrightarrow$ & $\uparrow$ \\
Remorin protein & $\downarrow$ & $\leftrightarrow$ & $\uparrow$ \\
Arginine decarboxylase & $\downarrow$ & $\leftrightarrow$ & $\leftrightarrow$ \\
Prephenate dehydratase & $\downarrow$ & $\uparrow$ & $\leftrightarrow$ \\
Polygalacturonase & $\downarrow$ & $\leftrightarrow$ & $\leftrightarrow$ \\
Peroxidase & $\downarrow$ & $\uparrow$ & $\uparrow$ \\
Glutamine synthase & $\downarrow$ & $\uparrow$ & $\leftrightarrow$ \\
Auxin responsive protein & $\downarrow$ & $\uparrow$ & $\leftrightarrow$ \\
\hline
\end{tabular}

lysis was conducted by cDNA-AFLP on leaves of AL35 plants grown on NP or P soil, the latter in the presence or in the absence of $G$. mosseae or $G$. intraradices (Cicatelli et al. 2012). A comparison of the cDNA-AFLP patterns of all four experimental conditions at S1 revealed that a large number of transcription-derived fragments (TDFs) were differentially modulated, and that AMF inoculation strongly modified the leaf transcriptome, partially restoring it to the control profile (Cicatelli et al. 2012). Most of the sequenced TDFs had similarities with database entries with known function and thus the identified TDFs were assigned to functional categories. The largest group of cDNA sequences $(18 \%$ of the total) corresponded to secondary plant metabolism, while defense, photosynthesis/energy, and intracellular traffic categories were also well represented (11\%). Thirteen genes whose expression was altered in mycorrhizal plants plus MT, ADC, and SPDS genes were selected as representing important functional categories, including secondary metabolism and defense, and analyzed by qRT-PCR.

Results showed that the vast majority of the selected genes was not affected or downregulated on $\mathrm{P}$ soil, but up-regulated by one or both AMF, especially G. mosseae (Tab. 6). This group includes defense genes such as thaumatin-like protein (TLP), glutathione synthase (GSH) and several MTs, but also genes involved in primary metabolism and transcription. Another group was down-regulated by HMs and restored to control levels or up-regulated in mycorrhizal plants (Tab. 6). They mainly belong to defense (MTs, remorin, peroxidase) and secondary metabolism (prephenate dehydratase) categories; the latter category included also ADC gene. Thus, most genes whose expression was strongly altered belong to stress-related functional categories. Most of these genes are reported for the first time in response to HM stress, and in particular to AMF colonization. It was also shown based on their expression pattern that the fungal species behave differently. In particular, G. mosseae appears to have a better capacity than $G$. intraradices to activate the plant's defense system as previously hypothesized in the case of cv. Villafranca, which was able to recover growth when cultivated on artificially $\mathrm{Cu}$ or $\mathrm{Zn}$ polluted soil (Lingua et al. 2008). These results were further corroborated by means of a MSAP (Methylation Sensitive Amplified Polymorphism) analysis aimed at highlighting epigenetic modifications of the DNA in the presence of HMs and/or AMF (Cicatelli et al. 2014).

A cDNA microarray approach was pursued in order to investigate the expression of some genes involved in antioxidant metabolism and metal homeostasis in leaves and roots of AL35 poplar plants inoculated with G. mosseae (Pallara et al. 2013). A total of twenty-six genes were considered, including eight superoxide dismutases (4 CuZnSod, 2 FeSod, 2 MnSod), three catalases (Cat), three ascorbate peroxidases $(A p x)$, one dehydroascorbate reductase (Dhar), one $\gamma$-glutamylcysteine synthase $(E c s)$, two glutathione reductases $(G r c)$, six metallothioneins (MT, only in roots), one metal transporter (Mtp), and one phytochelatin synthase $(P c s)$. Microarray data were validated by RT-qPCR on five of the above-mentioned genes. Plants 
grown on $\mathrm{P}$ soil generally exhibited higher transcript levels. However, some of the responses were clearly tissue specific; for instance, Mtp and Pcs were down-regulated in roots, but up-regulated in leaves. Similarly, MT1a and MT1b were down-regulated in roots. In general, ANOVA indicated that the metal treatment affected the transcription of a larger number of genes involved in antioxidant metabolism in leaves than in roots, sug gesting that metals in roots might be more abundant in the apoplast than in the symplast. Mycorrhizal plants grown on $\mathrm{P}$ soil grew better and showed a down-regulation of most antioxidant genes, in spite of a higher concentration of metals in their tissues, suggesting a higher degree of protection in this plant and a lower need of activating antioxidant pathways implicated in ROS scavenging. Similar results were previously reported in the case of mycorrhizal Pisum sativum (Rivera-Becerril et al. 2005) and Medicago truncatula (Aloui et al. 2011) under $\mathrm{Cd}$ stress.

\section{Proteomic analysis}

A proteomic analysis was performed on the leaves of clone AL35 inoculated or not with $G$. intraradices and grown in the greenhouse on P or NP soil (Lingua et al. 2012). Protein expression was evaluated four (S1), six (S2) and 16 (S3) months after transplanting of the cuttings. Though the description of all proteins modulated in the four different treatments and at three time points is beyond the scope of this paper, some general observations can be summarized here. Most of the identified proteins showing variations concerned the functional groups of "photosynthesis and carbon fixation" and "sugar metabolism". This is not surprising considering the analyzed organ. Secondly, the expression profiles varied significantly with time: at $\mathrm{S} 1$, 22 spots showed a differential expression between the four treatments, 52 at S2, and 66 at S3. At the first sampling time, a relevant number of proteins were involved in the functional group "protein folding", while at the second and third sampling times this group was less represented and the previously missing groups of "oxidative damage" and "glutathione metabolism" were represented. Furthermore, at S1 all the modulated spots were affected by fungal inoculation (as shown by two-way ANOVA), while only $25 \%$ of them were affected by the metal treatment. At S2 the situation was reversed with most of the spots (94\%) affected by the metal treatment and only $42 \%$ of them influenced by the fungal inoculation. At the last sampling, both factors were equally important.

\section{Conclusions}

Our results demontrate the feasibility of establishing a multi-clonal poplar stool bed on a highly $\mathrm{Cu}$ - and $\mathrm{Zn}$-contaminated soil for phytoremediation purposes. The broad genetic variability of natural poplar collections allow high performing clones to be selected and used for soil recovery. One of the selected clones (AL35) showed outstanding features for both $\mathrm{Cu}$ and $\mathrm{Zn}$ phytoextraction and/or phytostabilization purposes. In addition, results show that plant association with bacterial and fungal microorganisms is able to greatly improve plant growth performance on a metal-polluted soil. Evidence is provided that stress recovery may arise from the protective role of MTs and PAs, whose genes are specifically up-regulated by the plant-AMF interaction. Large-scale molecular analyses confirm that the symbiosis determines several changes at the transcriptional/translational levels, which presumably underlie the improved performance of plants under stressful conditions. Data resulting from the proteomic analysis shall be integrated and compared with those from transcriptomic and biochemical analyses, according to a system biology approach, in order to exploit the different sensitivity of the various techniques, and provide a general framework for the plant's response to HMs. In the future, the acquired knowledge on candidate genes/proteins involved in AMF-enhanced poplar tolerance could represent the basis for molecular engineering efforts to obtain tolerant plants to be used in phytoremediation activities.

\section{Acknowledgments}

This research was supported by funds from the Italian Ministry for Education, University and Scientific Research (PRIN 2003 077418 and PRIN 2005055337) and from the Italian Ministry of the Environment, Land and Sea Protection ("Research and development in biotechnology applied to the protection of the environment") in collaboration with The People's Republic of China to S.C.; it is also part of the doctorate program carried out by A.C. at the "Federico II" University of Naples (IT).

\section{References}

Abou-Shanab R, Ghanem K, Ghanem N, Al Kolaibe A (2008). The role of bacteria on heavymetal extraction and uptake by plants growing on multi-metal-contaminated soils. World Journal of Microbiology and Biotechnology 24: 253262. - doi: 10.1007/s11274-007-9464-X

Akashi K, Nishimura N, Ishida Y, Yokota A (2004). Potent hydroxyl radical-scavenging activity of drought-induced type- 2 metallothionein in wild watermelon. Biochemical and Biophysical Research Communications 323: 72-78. - doi: 10.1016/j.bbrc.2004.08.056

Alcazar R, Altabella T, Marco F, Bortolotti C, Reymond M, Koncz C, Carrasco P, Tiburcio AF (2010). Polyamines: molecules with regulatory functions in plant abiotic stress tolerance. Planta
231: 1237-1249. - doi: 10.1007/s00425-010-11 30-0

Ali NA, Bernal MP, Ater M (2004). Tolerance and bioaccumulation of cadmium by Phragmites australis grown in the presence of elevated concentrations of cadmium, copper, and zinc. Aquatic Botany 80: 163-176. - doi: 10.1016/j.aquabot. 2004.08.008

Aloui A, Recorbet G, Robert F, Schoefs B, Bertrand M, Henry C, Gianinazzi-Pearson V, Dumas-Gaudot E, Aschi-Smit S (2011). Arbuscular mycorrhizal symbiosis elicits shoot proteome changes that are modified during cadmium stress alleviation in Medicago truncatula. BMC Plant Biology 11: 75-82. - doi: 10.1186/1471-2229-11-75

Aravanopoulos FA, Kim KH, Zsuffa L (1999). Genetic diversity of superior Salix clones selected for intensive forestry plantations. Biomass and Bioenergy 16: 249-255. - doi: 10.1016/S096 1-9534(98)00013-0

Aronsson P, Perttu K (2001). Willow vegetation filters for wastewater treatment and soil remediation combined with biomass production. Forestry Chronicle 77: 293-299. - doi: 10.5558/tfc77293-

Bagni N, Torrigiani P (1992). Polyamines: a new class of growth substances. In: "Progress in plant growth regulation" (Karseen CM, van Loon LC, Vreugdenhil D eds). Kluwer Academic Publishers, Dordrecht, The Netherlands, pp. 264-275. - doi: 10.1007/978-94-011-2458-4 29

Balestrazzi A, Botti S, Zelasco S, Biondi S, Franchin C, Calligari P, Racchi M, Turchi A, Lingua G, Berta G, Carbonera D (2009). Expression of the PsMT (A1) gene in white poplar engineered with the MAT system is associated with heavy metal tolerance and protection against 8 hydroxy-2'-deoxyguanosine mediated-DNA damage. Plant Cell Reports 28: 1179-1192. - doi: 10.1007 /s00299-009-0719-x

Belimov AA, Safronova VI, Sergeyeva TA, Egorova TN, Matveyeva VA, Tsyganov VE, Borisov AY, Tikhonovich IA, Kluge C, Preisfeld A, Dietz KJ, Stepanok VV (2001). Characterization of plant growth promoting rhizobacteria isolated from polluted soils and containing 1-aminocyclopropane-1-carboxylate deaminase. Canadian Journal of Microbiology 47: 642-652. - doi: 10.1139/w01-062

Bois G, Piche Y, Fung MYP, Khasa DP (2005). Mycorrhizal inoculum potentials of pure reclamation materials and revegetated tailing sands from the Canadian oil sand industry. Mycorrhiza 15: 149-158. - doi: 10.1007/s00572-004-0315-4 Borghi M, Tognetti R, Monteforti G, Sebastiani L (2007). Responses of Populus $x$ euramericana $(P$. deltoides $x$ P. nigra) clone Adda to increasing copper concentrations. Environmental and Experimental Botany 61: 66-73. - doi: 10.1016/j. envexpbot.2007.03.001

Castiglione S, Cicatelli A, Lupi R, Patrignani G, Fossati T, Brundu G, Sabatti M, van Loo M, Lexer C (2010). Genetic structure and introgression in riparian populations of Populus alba $\mathrm{L}$. Plant Biosystems 144: 656-668. - doi: 10.1080/1 
1263504.2010.496188

Castiglione S, Todeschini V, Franchin C, Torrigiani P, Gastaldi D, Cicatelli A, Rinaudo C, Berta G, Biondi S, Lingua G (2009). Clonal differences in survival capacity, copper and zinc accumulation, and correlation with leaf polyamine levels in poplar: a large-scale field trial on heavily polluted soil. Environmental Pollution 157: 2108-2117. - doi: 10.1016/j.envpol.2009.02.011 Castiglione S, Franchin C, Fossati T, Lingua G, Torrigiani P, Biondi S (2007). High zinc concentrations reduce rooting capacity and alter metallothionein gene expression in white poplar (Populus alba L. cv. Villafranca). Chemosphere 67: 1117-1126. - doi: 10.1016/j.chemosphere.2006 11.039

Christophersen HM, Smith FA, Smith SE (2012). Unraveling the influence of arbuscular mycorrhizal colonization on arsenic tolerance in Medicago: Glomus mosseae is more effective than $G$. intraradices, associated with lower expression of root epidermal Pi transporter genes. Frontiers in Physiology 3: 91. - doi: 10.3389/fphys.2012.000 91

Cicatelli A, Todeschini V, Lingua G, Biondi S, Torrigiani P, Castiglione S (2014). Epigenetic control of heavy metal stress response in mycorrhizal versus non-mycorrhizal poplar plants. Environmental Science and Pollution Research 21: 1723-1737. - doi: 10.1007/s11356-013-2072-4

Cicatelli A, Lingua G, Todeschini V, Biondi S, Torrigiani P, Castiglione S (2010). Arbuscular mycorrhizal fungi restore normal growth in a white poplar clone grown on heavy metal-contaminated soil, and this is associated with upregulation of foliar metallothionein and polyamine biosynthetic gene expression. Annals of Botany 106: 791-802. - doi: 10.1093/aob/mcq170

Cicatelli A, Lingua G, Todeschini V, Biondi S, Torrigiani P, Castiglione S (2012). Arbuscular mycorrhizal fungi modulate the leaf transcriptome of a Populus alba L. clone grown on a zinc and copper-contaminated soil. Environmental and Experimental Botany 75: 25-35. - doi 10.1016/j.envexpbot.2011.08.012

Clijsters H, Cuypers A, Vangronsveld J (1999). Physiological responses to heavy metals in higher plants: defence against oxidative stress. Zeitschrift fur Naturforschung C-A Journal of Biosciences 54: 730-734.

Cobbett C, Goldsbrough P (2002). Phytochelatins and metallothioneins: roles in heavy metal detoxification and homeostasis. Annual Review of Plant Biology 53: 159-182. - doi: 10.1146/annurev.arplant.53.100301.135154

Copetta A, Lingua G, Berta G (2006). Effects of three AM fungi on growth, distribution of glandular hairs, and essential oil production in $\mathrm{Oci}$ mum basilicum L. var. Genovese. Mycorrhiza 16: 485-494. - doi: 10.1007/s00572-006-0065-6 Dabrowska G, Hrynkiewicz K, Trejgell A (2012). Do arbuscular mycorrhizal fungi affect metallothionein Mt2 expression in Brassica napus L. roots? Acta Biologica Cracoviensia Series Botanica 54: 34-39.

Di Baccio D, Galla G, Bracci T, Andreucci A,
Barcaccia G, Tognetti R, Sebastiani L (2011). Transcriptome analyses of Populus $x$ euramericana clone I-214 leaves exposed to excess zinc. Tree Physiology 31: 1293-1308. - doi: 10.1093/ treephys/tpr106

Dickinson NM, Pulford ID (2005). Cadmium phytoextraction using short-rotation coppice Salix: the evidence trail. Environment International 31: 609-613. - doi: 10.1016/j.envint.2004. 10.013

Dos Santos Utmazian MN, Wenzel WW (2007). Cadmium and zinc accumulation in willow and poplar species grown on polluted soils. Journal of Plant Nutrition and Soil Science 170: 265272. - doi: 10.1002/jpln.200622073

Dos Santos Utmazian MN, Wieshammer G, Vega R, Wenzel WW (2007). Hydroponic screening for metal resistance and accumulation of cadmium and zinc in twenty clones of willows and poplars. Environmental Pollution 148: 155-165. - doi: 10.1016/j.envpol.2006.10.045

Doty SL (2008). Enhancing phytoremediation through the use of transgenics and endophytes. New Phytologist 179: 318-333. - doi: 10.1111/j. 1469-8137.2008.02446.x

Edreva A, Velikova V, Tsonev T (2007). Phenylamides in plants. Russian Journal of Plant Physiology 54: 287-301. - doi: 10.1134/S102144370 7030016

Fossati T, Patrignani G, Zapelli I, Sabatti M, Sala F, Castiglione S (2004). Development of molecular markers to assess the level of introgression of Populus tremula into P. alba natural populations. Plant Breeding 123: 382-385. - doi: 10. 1111/j.1439-0523.2004.00979.x

Franchin C, Fossati T, Pasquini E, Lingua G, Castiglione S, Torrigiani P, Biondi S (2007). High concentrations of zinc and copper induce differential polyamine responses in micropropagated white poplar (Populus alba). Physiologia Plantarum 130: 77-90. - doi: 10.1111/j.1399-3054.20 07.00886.x

Frey B, Ruedt A, Widmer F (2010). Changes in rhizosphere bacterial populations during phytoextraction of heavy metal contaminated soil with poplar. Plant Biosystems 144: 392-395. doi: $10.1080 / 11263501003718588$

Gamalero E, Cesaro P, Cicatelli A, Todeschini V, Musso C, Castiglione S, Fabiani A, Lingua G (2012). Poplar clones of different sizes, grown on a heavy metal polluted site, are associated with microbial populations of varying composition. Science of the Total Environment 425: 262270. - doi: 10.1016/j.scitotenv.2012.03.012

Gamalero E, Lingua G, Berta G, Glick BR (2009). Beneficial role of plant growth promoting bacteria and arbuscular mycorrhizal fungi on plant responses to heavy metal stress. Canadian Journal of Microbiology 55: 501-514. - doi: 10.1139/ W09-010

Gohre V, Paszkowski U (2006). Contribution of the arbuscular mycorrhizal symbiosis to heavy metal phytoremediation. Planta 223: 1115-1122. - doi: 10.1007/s00425-006-0225-0

Groppa M, Benavides M (2008). Polyamines and abiotic stress: recent advances. Amino Acids 34: 35-45. - doi: 10.1007/s00726-007-0501-8
Groppa MD, Tomaro ML, Benavides MP (2007). Polyamines and heavy metal stress: the antioxidant behavior of spermine in cadmium- and copper-treated wheat leaves. Biometals 20: 185-195. - doi: 10.1007/s10534-006-9026-y

Guerrieri E, Lingua G, Digilio MC, Massa N, Berta G (2004). Do interactions between plant roots and the rhizosphere affect parasitoid behaviour? Ecological Entomology 29: 753-756. doi: 10.1111/j.0307-6946.2004.00644.x

Hanfrey C, Franceschetti M, Mayer MJ, Illingworth C, Michael AJ (2002). Abrogation of upstream open reading frame-mediated translational control of a plant S-adenosylmethionine decarboxylase results in polyamine disruption and growth perturbations. Journal of Biological Chemistry 277: 44131-44139. - doi: 10.1074/jbc.M2 06161200

Hartmann A, Lemanceau P, Prosser JI (2008). Multitrophic interactions in the rhizosphere - rhizosphere microbiology: at the interface of many disciplines and expertises. Fems Microbiology Ecology 65: 179. - doi: 10.1111/j.1574-6941.20 08.00558.x

Hassinen V, Vallinkoski VM, Issakainen S, Tervahauta A, Karenlampi S, Servomaa K (2009). Correlation of foliar MT2b expression with $\mathrm{Cd}$ and $\mathrm{Zn}$ concentrations in hybrid aspen (Populus tremula $x$ tremuloides) grown in contaminated soil. Environmental Pollution 157: 922-930. doi: 10.1016/j.envpol.2008.10.023

He CQ, Tan G, Liang X, Du W, Chen Y, Zhi G, Zhu Y (2010). Effect of Zn-tolerant bacterial strains on growth and $\mathrm{Zn}$ accumulation in Orychophragmus violaceus. Applied Soil Ecology 44: 1-5. - doi: 10.1016/j.apsoil.2009.07.003

Hohnjec N, Vieweg ME, Puhler A, Becker A, Kuster H (2005). Overlaps in the transcriptional profiles of Medicago truncatula roots inoculated with two different Glomus fungi provide insights into the genetic program activated during arbuscular mycorrhiza. Plant Physiology 137: 12831301. - doi: 10.1104/pp.104.056572

Hua J, Lin X, Bai J, Shao Y, Yin R, Jiang Q (2010). Effects of arbuscular mycorrhizal fungi and earthworm on nematode communities and arsenic uptake by maize in arsenic-contaminated soils. Pedosphere 20: 163-173. - doi: 10.1016/S1 002-0160(10)60004-5

Kohler A, Blaudez D, Chalot M, Martin F (2004). Cloning and expression of multiple metallothioneins from hybrid poplar. New Phytologist 164: 83-93. - doi: 10.1111/j.1469-8137.2004.01168.x Kopponen P, Utriainen M, Lukkari K, Suntioinen S, Karenlampi L, Karenlampi S (2001). Clonal differences in copper and zinc tolerance of birch in metal-supplemented soils. Environmental Pollution 112: 89-97. - doi: 10.1016/S0269-7491 (00)00096-8

Kuffner M, Puschenreiter M, Wieshammer G, Gorfer M, Sessitsch A (2008). Rhizosphere bacteria affect growth and metal uptake of heavy metal accumulating willows. Plant and Soil 304: 35-44. - doi: 10.1007/s11104-007-9517-9

Kusano T, Berberich T, Tateda C, Takahashi Y (2008). Polyamines: essential factors for growth 
and survival. Planta 228: 367-381. - doi: 10 1007/s00425-008-0772-7

Kuthanova A, Gemperlova L, Zelenkova S, Eder J, Machackova I, Opatrny Z, Cvikrova M (2004). Cytological changes and alterations in polyamine contents induced by cadmium in tobacco BY-2 cells. Plant Physiology and Biochemistry 42 149-156. - doi: 10.1016/j.plaphy.2003.11.003

Laureysens I, Blust R, De Temmerman L, Lemmens C, Ceulemans R (2004). Clonal variation in heavy metal accumulation and biomass production in a poplar coppice culture. I. Seasonal variation in leaf, wood and bark concentrations. Environmental Pollution 131: 485-494. - doi 10.1016/j.envpol.2004.02.009

Lebeau T, Braud A, Jezequel K (2008). Performance of bioaugmentation-assisted phytoextraction applied to metal contaminated soils: a review. Environmental Pollution 153: 497-522. doi: 10.1016/j.envpol.2007.09.015

Lei Y, Korpelainen H, Li C (2007). Physiologica and biochemical responses to high $\mathrm{Mn}$ concentrations in two contrasting Populus cathayana populations. Chemosphere 68: 686-694. - doi: 10.1016/j.chemosphere.2007.01.066

Lingua G, D’Agostino G, Massa N, Antosiano M, Berta G (2002). Mycorrhiza-induced differential response to a yellows disease in tomato. Mycorrhiza 12: 191-198. - doi: 10.1007/s00572-0020171-z

Lingua G, Bona E, Todeschini V, Cattaneo C, Marsano F, Berta G, Cavaletto M (2012). Effects of heavy metals and arbuscular mycorrhiza on the leaf proteome of a selected poplar clone: a time course analysis. Plos One 7 (6): e38662. doi: 10.1371/journal.pone.0038662

Lingua G, Franchin C, Todeschini V, Castiglione S, Biondi S, Burlando B, Parravicini V, Torrigiani P, Berta G (2008). Arbuscular mycorrhizal fungi differentially affect the response to high zinc concentrations of two registered poplar clones. Environmental Pollution 153: 137-147. doi: 10.1016/j.envpol.2007.07.012

Liu J, Wu L, Wei S, Xiao X, Su C, Jiang P, Song Z, Wang T, Yu Z (2007). Effects of arbuscula mycorrhizal fungi on the growth, nutrient uptake and glycyrrhizin production of licorice (Glycyrrhiza uralensis Fisch). Plant Growth Regulation 52: 29-39. - doi: 10.1007/s10725-007-91742

Lovaas E (1997). Antioxidative and metal-chelating effects of polyamines. Advances in Pharmacology 38: 119-149. - doi: 10.1016/S1054-3589 (08)60982-5

Martin Tanguy J (1997). Conjugated polyamines and reproductive development: biochemical, molecular and physiological approaches. Physiologia Plantarum 100: 675-688. - doi: 10.1111/j. 1399-3054.1997.tb03074.x

Mrnka L, Kuchar M, Cieslarova Z, Matejka P, Szakova J, Tlustos P, Vosatka M (2012). Effects of endo- and ectomycorrhizal fungi on physiological parameters and heavy metals accumulation of two species from the family Salicaceae. Water Air and Soil Pollution 223: 399-410. - doi: 10.1007/s11270-011-0868-8
Ouziad F, Hildebrandt U, Schmelzer E, Bothe H (2005). Differential gene expressions in arbuscular mycorrhizal-colonized tomato grown under heavy metal stress. Journal of Plant Physiology 162: 634-649. - doi: 10.1016/j.jplph.2004.09. 014

Pallara G, Todeschini V, Lingua G, Camussi A, Racchi ML (2013). Transcript analysis of stress defence genes in a white poplar clone inoculated with the arbuscular mycorrhizal fungus Glomus mosseae and grown on a polluted soil. Plant Physiology and Biochemistry 63: 131-139. - doi: 10.1016/j.plaphy.2012.11.016

Park MS, Jung SR, Lee KH, Lee MS, Do JO, Kim SB, Bae KS (2006). Chryseobacterium soldanellicola sp. nov. and Chryseobacterium taeanense sp. nov., isolated from roots of sand-dune plants. International Journal of Systematic and Evolutionary Microbiology 56: 433-438. - doi: 10.1099/ ijs.0.63825-0

Pilon-Smits E (2005). Phytoremediation. Annual Review of Plant Biology 56: 15-39. - doi: 10. 1146/annurev.arplant.56.032604.144214

Piotrowska-Seget Z, Cycon M, Kozdroj J (2005). Metal-tolerant bacteria occurring in heavily polluted soil and mine spoil. Applied Soil Ecology 28: 237-246. - doi: 10.1016/j.apsoil.2004.08.001 Prabhavathi V, Rajam MV (2007). Mannitol-accumulating transgenic eggplants exhibit enhanced resistance to fungal wilts. Plant Science 173: 50-54. - doi: 10.1016/j.plantsci.2007.04.004

Punshon T, Dickinson NM (1997). Acclimation of Salix to metal stress. New Phytologist 137: 303314. - doi: 10.1046/j.1469-8137.1997.00802.x Quoreshi A, Khasa D (2008). Effectiveness of mycorrhizal inoculation in the nursery on root colonization, growth, and nutrient uptake of aspen and balsam poplar. Biomass and Bioenergy 32: 381-391. - doi: 10.1016/j.biombioe.2007.10.010 Rajkumar M, Sandhya S, Prasad M, Freitas H (2012). Perspectives of plant-associated microbes in heavy metal phytoremediation. Biotechnology Advances 30: 1562-1574. - doi: 10.1016/j.biotechadv.2012.04.011

Rivera-Becerril F, Metwally A, Martin-Laurent F, Van Tuinen D, Dietz KJ, Gianinazzi S, Gianinazzi-Pearson V (2005). Molecular responses to cadmium in roots of Pisum sativum L. Water Air and Soil Pollution 168: 171-186. - doi: 10.1007/ s11270-005-1247-0

Rodriguez R, Redman R (2008). More than 400 million years of evolution and some plants still can't make it on their own: plant stress tolerance via fungal symbiosis. Journal of Experimental Botany 59: 1109-1114. - doi: 10.1093/jxb/erm3 42

Sannazzaro AI, Echeverria M, Alberto EO, Ruiz OA, Menendez AB (2007). Modulation of polyamine balance in Lotus glaber by salinity and arbuscular mycorrhiza. Plant Physiology and Biochemistry 45: 39-46. - doi: 10.1016/j.plaphy.20 06.12 .008

Schüßler A, Walker C (2010). The Glomeromyco$t a$ : a species list with new families and new genera. The Royal Botanic Garden Edinburgh, The Royal Botanic Garden Kew, Botanische Staats- sammlung Munich, and Oregon State University, Gloucester, UK, pp. 56. [online] URL: http:// schuessler.userweb.mwn.de/amphylo/Schuessler \&Walker2010 Glomeromycota.pdf

Sebastiani L, Scebba F, Tognetti R (2004). Heavy metal accumulation and growth responses in poplar clones Eridano (Populus deltoides $x \mathrm{ma}$ ximowiczii) and I-214 (P. x euramericana) exposed to industrial waste. Environmental and Experimental Botany 52: 79-88. - doi: 10.1016/j.envexpbot.2004.01.003

Sharma SS, Dietz KJ (2006). The significance of amino acids and amino acid-derived molecules in plant responses and adaptation to heavy metal stress. Journal of Experimental Botany 57: 711726. - doi: 10.1093/jxb/erj073

Shilev SI, Ruso J, Puig A, Benlloch M, Jorrin J, Sancho E (2001). Rhizospheric bacteria promote sunflower (Helianthus annuus L.) plant growth and tolerance to heavy metals. Minerva Biotecnologica 13: 37-39.

Smith SE, Read DJ (1997). Mycorrhizal symbiosis $\left(2^{\text {nd }}\right.$ edn). Academic Press, London, UK, pp. 605.

Smith SE, Facelli E, Pope S, Smith F (2010). Plant performance in stressful environments: interpreting new and established knowledge of the roles of arbuscular mycorrhizas. Plant and Soil 326: 3-20. - doi: 10.1007/s11104-009-9981-5

Smulders M, Cottrell J, Lefevre F, van der Schoot J, Arens P, Vosman B, Tabbener H, Grassi F, Fossati T, Castiglione S, Krystufek V, Fluch S, Burg K, Vornam B, Pohl A, Gebhardt K, Alba N, Agundez D, Maestro C, Notivol E, Volosyanchuk R, Pospiskova M, Bordacs S, Bovenschen J, van Dam B, Koelewijn H, Halfmaerten D, Ivens B, van Slycken J, Broeck A, V, Storme V, Boerjan W (2008). Structure of the genetic diversity in black poplar (Populus nigra L.) populations across European river systems: consequences for conservation and restoration. Forest Ecology and Management 255: 13881399. - doi: 10.1016/j.foreco.2007.10.063

Solis-Dominguez FA, Valentin-Vargas A, Chorover J, Maier RM (2011). Effect of arbuscular mycorrhizal fungi on plant biomass and the rhizosphere microbial community structure of mesquite grown in acidic lead/zinc mine tailings. Science of the Total Environment 409: 10091016. - doi: 10.1016/j.scitotenv.2010.11.020

Takacs D, Radimszky L, Nemeth T (2005). The arbuscular mycorrhizal status of poplar clones selected for phytoremediation of soils contaminated with heavy metals. Zeitschrift fur Naturforschung CA Journal of Biosciences 60: 357361. [online] URL: http://www.znaturforsch.$\mathrm{com} / \mathrm{ac} / \mathrm{v} 60 \mathrm{c} / \mathrm{s} 60 \mathrm{c} 0357$.pdf?origin=publication_ detail

Thewys T, Witters N, Meers E, Vangronsveld J (2010). Economic viability of phytoremediation of a cadmium contaminated agricultural area using energy maize. Part II: economics of anaerobic digestion of metal contaminated maize in Belgium. International Journal of Phytoremediation 12: 663-679. - doi: 10.1080/15226514.2010 .493188 
Todeschini V, Franchin C, Castiglione S, Burlando B, Biondi S, Torrigiani P, Berta G, Lingua G (2007). Responses to copper of two registered poplar clones inoculated or not with arbuscular mycorrhizal fungi. Caryologia 60: 146-155. doi: 10.1080/00087114.2007.10589564

Tognetti R, Cocozza C, Marchetti M (2013). Shaping the multifunctional tree: the use of Salicaceae in environmental restoration. iForest 6 : 37-47. - doi: 10.3832/ifor0920-006

Tsai CJ, Harding SA, Tschaplinski TJ, Lindroth RL, Yuan Y (2006). Genome-wide analysis of the structural genes regulating defense phenylpropanoid metabolism in Populus. New Phytologist 172: 47-62. - doi: 10.1111/j.1469-8137.20 06.01798.x
Tseng CC, Wang JY, Yang L (2009). Accumulation of copper, lead, and zinc by in situ plants inoculated with AM fungi in multicontaminated soil. Communications in Soil Science and Plant Analysis 40: 3367-3386. - doi: 10.1080/0010362 0903325968

Tuskan GA, DiFazio SP, Teichmann T (2004).

Poplar genomics is getting popular: the impact of the poplar genome project on tree research. Plant Biology 6: 2-4. - doi: 10.1055/s-2003-44715

van der Lelie D, Taghavi S, Monchy S, Schwender J, Miller L, Ferrieri R, Rogers A, Wu X, Zhu W, Weyens N, Vangronsveld J, Newman L (2009). Poplar and its bacterial endophytes: coexistence and harmony. Critical Reviews in Plant Sciences 28: 346-358. - doi: 10.1080/073526809
03241204

Velikova V, Yordanov I, Edreva A (2000). Oxidative stress and some antioxidant systems in acid rain-treated bean plants - protective role of exogenous polyamines. Plant Science 151: 59-66. doi: 10.1016/S0168-9452(99)00197-1

Zalesny RS, Bauer EO, Hall RB, Zalesny JA, Kunzman J, Rog CJ, Riemenschneider DE (2005). Clonal variation in survival and growth of hybrid poplar and willow in an in situ trial on soils heavily contaminated with petroleum hydrocarbons. International Journal of Phytoremediation 7: 177-197. - doi: 10.1080/16226510500 214632 